Investigating students' understanding of the relationship between academic integrity and professional integrity in construction

Dr. Nicholas Tymvios, UNC Charlotte

Dr. John Hildreth, University of North Carolina, Charlotte 


\section{Investigating students' understanding of the relationship between academic integrity and professional integrity in construction}

It is assumed that construction management and civil engineering technology students are aware of what constitutes a violation of academic integrity (AI). Academic integrity is addressed at the beginning of every course they have taken though the various syllabi and discussions with instructors and other academic personnel. Violations of professional integrity (PI) are usually addressed through various courses and students are expected to have some understanding as to what constitutes acceptable behavior regarding maters of PI. It is believed though, that students cannot grasp the relationships between violations of AI to their equivalent violations of PI.

To investigate the level of students' understanding of that relationship, the authors conducted a series of three separate and anonymous surveys from representative construction management and civil engineering technology undergraduate classes at a four year institution. The first survey investigated the level of understanding of what constitutes a violation of AI. This was performed to validate the assumption that students understand AI and they recognize a violation when they see one. The survey included a series of actions such as "Taking an exam for another student" and the students were asked to identify if these actions can be described as "cheating", "unethical but not cheating", and "neither unethical not cheating". In addition the students were asked to state the number of times they performed or witnessed these actions within the past year.

The second survey looked at the students' understanding of what constitutes a violation of PI in the construction industry, by answering whether several scenarios represent a violation of PI or not. The third survey in the series attempted to investigate whether the students could link the violations of AI to their equivalent violations of PI. The time between the surveys was between 1 to 2 weeks and students from all undergraduate levels were surveyed.

Key Words: Academic Integrity, Professional Integrity, Ethics, Construction 


\section{Introduction}

It is evident that academic integrity violations are commonplace in almost all universities in the US and other countries ${ }^{1}$. Several studies have been published that show student's views on what constitutes academic integrity, as well as their self-admitted frequency of violations of academic integrity $^{2,3}$. Previous research has also shown that students cheating in college are also more likely to cheat in graduate school and professional training, engage in unethical behavior in their professional lives, and cheat on their taxes ${ }^{4}$.

\section{Background}

Nearly all professional associations have developed codes of conduct that provide guidelines to their members for their interaction with their clients and colleagues as well as expectations towards the profession. Examples of such codes of ethics include the ones produced by the American Society of Civil Engineers, American Institute of Architects and the National Society of Professional Engineers ${ }^{5-7}$. Memberships in these organizations provide professionals with privileges that are essential to their day-to-day work, and any potential violations of the code of ethics will cause them to lose these privileges.

Contractors also have a professional association; the Construction Management Association of North America (CMAA), with a similar code of ethics as other organizations ${ }^{8}$. Membership to CMAA is not compulsory or essential for a contractor to operate in the construction industry, as a result not all construction contractors are members, and repercussions to unethical behavior have very little impact.

Students enrolled in Construction Management and Engineering Technology programs will eventually become future construction contractors. It is imperative for them to realize the importance of ethics and how ethics relate to their profession. This paper investigates the level of understanding students have on academic integrity and student ethics, and how academic integrity relates to professional integrity.

\section{Methodology and Results}

In order to investigate the level of understanding students have on the relationship between academic and professional integrity, three surveys were conducted. The first survey looked at students' level of understanding as to what constitutes a violation of academic integrity; the second looked at their views on possible ethical violations in the construction industry; while the third asked students to link possible connections between violations of academic integrity and violations of professional ethics. 
The surveys were conducted during representative classes that would sample responses from freshmen, sophomore, junior and senior students enrolled in either the civil engineering technology or construction management programs within the department. These classes were a freshman materials class, a sophomore surveying class, a junior structures class, and a senior highway design and construction class. They were paper surveys that were administered at the beginning of each sampled class. The authors spent some time explaining the reasons for the survey and instructed the students to complete them anonymously. After that introduction, the authors would leave the room, and a graduate student supervised the classes while the students completed the surveys. Completed surveys were collected in a ballot box and returned to the authors. All three surveys were color coded; the first one was blue, the second pink and the third green.

\section{First Survey}

The first survey was adapted from a series of research projects ${ }^{4,9,10}$ that used a 139 question survey designed to understand the perceptions and attitudes on cheating from engineering students. The survey was previously distributed to engineering students at several institutions that included four-year public and private universities as well as community colleges with preengineering programs.

For this research the authors only used a portion of that survey, and specifically a list of twenty actions where students were asked to state if they consider these actions to be "cheating", "Unethical but not cheating", or "Neither unethical nor cheating". The students were then asked to state the number of times they performed these actions in the past year. A total of 162 students responded to the first survey, of which $86.4 \%$ of them were male, and $9.9 \%$ female. In addition $13.6 \%$ of the students stated they were freshmen, $17.9 \%$ sophomores, $32.1 \%$ juniors and $34.6 \%$ seniors. The percentages for both the "M/F" question and the "Year" do not sum to $100 \%$ since the students had the option to leave that question blank. The survey questions and the results are shown in Table 1.

When the results of this survey were compared with the results from ${ }^{4}$ it was observed that the students responded similarly. For each action the highest percentage of responses occurred for the same consideration with the only exceptions being actions "P" (Working in groups on webbased quizzes) and "Q" (Working in groups on take-home exams). In the survey by ${ }^{4}$, the highest percentage for the consideration of both actions was "Cheating", while in the current study, the students considered action " $P$ " to be "Unethical but not cheating" and action " $Q$ " to be "Neither Unethical nor cheating". Regarding the frequency of cheating behavior the only difference in the occurrence of the highest percentage was for action " $\mathrm{C}$ " (Asking another student about questions on an exam you have not taken). The highest percentage of students surveyed by ${ }^{4}$, stated that their frequency for action " $C$ " was " $3+$ " while in the current study, the highest percentage of students stated that the highest percentage of frequency for that action was " 0 ". 
Table 1: First survey questions and results

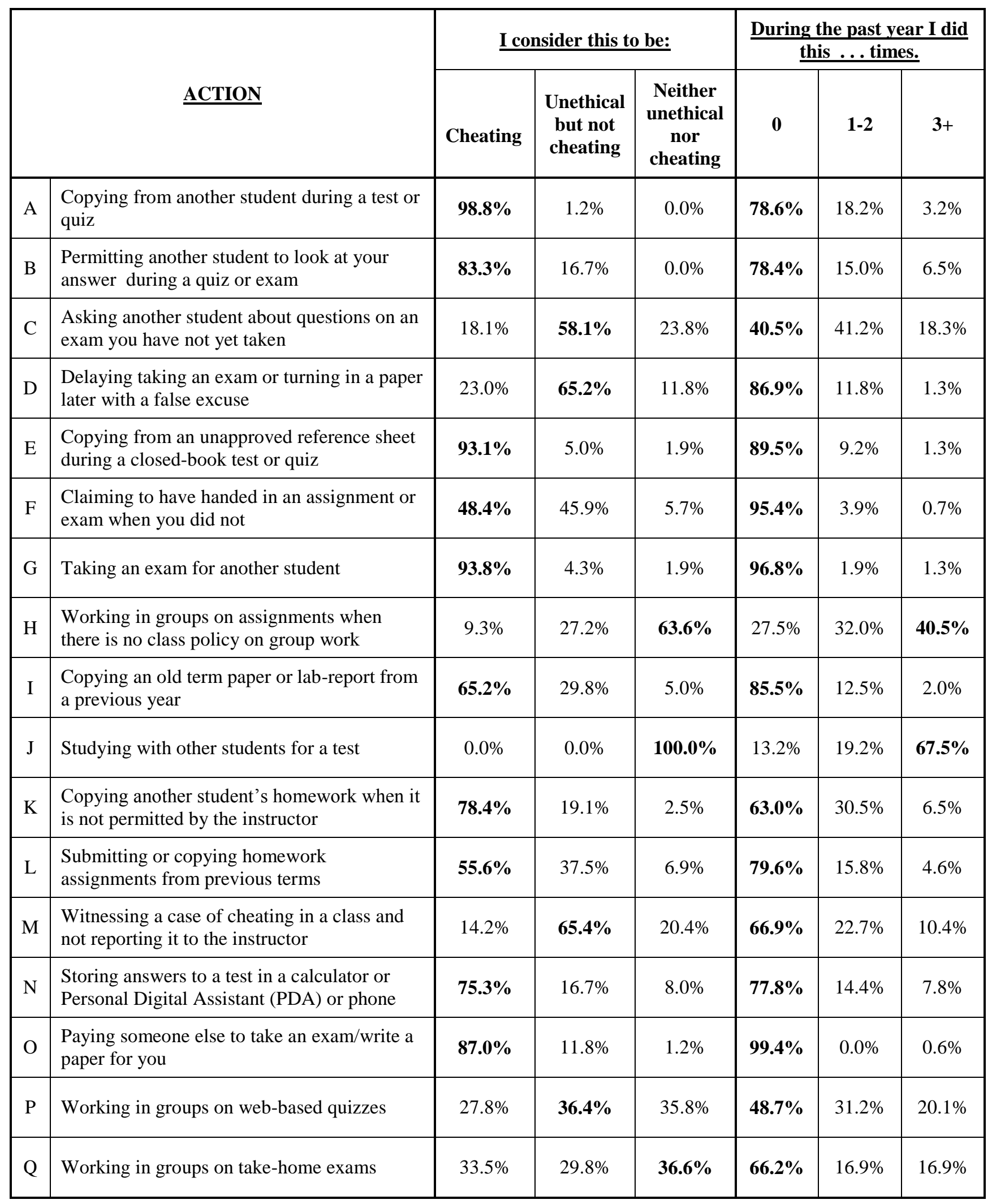


The results of the first survey were comparable with the results of ${ }^{4}$ with some minor exceptions, and the conclusions were similar to that of the original research.

\section{Second Survey}

The second survey attempted to investigate whether certain actions in the construction industry are viewed by students as "Ethical" or "Unethical". The students were also instructed to state "I don't know" in case they were not aware of the action, or they were not sure if the action was ethical or unethical. The authors did not identify in past literature a similar survey where students were asked to consider construction industry ethical violations. They developed a list of thirteen actions in the survey using their own industry experience, and other sources of literature on the topic of ethical violations in construction ${ }^{11,12}$.

A total of 162 students responded to the second survey, of which $88.2 \%$ of them were male, and $8.4 \%$ female. In addition $14.0 \%$ of the students stated they were freshmen, $15.2 \%$ sophomores, $30.3 \%$ juniors and $38.8 \%$ seniors. The survey questions and the results are shown in Table 2.

As observed, the students identified the majority of the actions to be unethical with the exception of actions "A" (Selecting a contractor based on lowest bid), "L" (Contractor delaying payment to a subcontractor until receiving payment from owner) and "M" (Installing approved but not preferred equipment on a project), where the highest percentage of the responses was identified as "Ethical" by the students. The results of the survey show that the majority of the students recognized the actions that are unethical and that even with their limited exposure to the industry, they acquired the necessary knowledge to identify unethical behavior in construction practice.

\section{Third Survey}

The final survey aimed in identifying whether construction management and civil engineering technology students could link violations of academic integrity with violations of professional ethics. Since the violations cannot be directly compared, the authors developed a survey where students were asked to match "Academic Integrity Actions" with "Professional Integrity Actions". The survey listed five academic integrity actions, and a series of eight professional integrity actions. Once again, there was no previous literature identified that attempted such a comparison, and the authors developed the survey from their own professional experience. A total of 161 students responded to the third survey, of which $90.1 \%$ of them were male, and $7.5 \%$ female. In addition $14.3 \%$ of the students stated they were freshmen, $16.1 \%$ sophomores, $31.1 \%$ juniors and $37.9 \%$ seniors. The survey action statements and the results are shown in Table 3.

As observed, 89.5\% of the students identified that "Witnessing a case of cheating in class and not reporting it to the instructor" is more similar to "Not reporting a co-worker stealing tools", while $90.0 \%$ of the students identified "Claiming to have handed in an assignment or an exam when you did not" with "Claiming to have submitted required documents when you have not". These 
two "matchings" had the highest percentage and the authors believe that they were straightforward.

Table 2: Second survey questions and results

\begin{tabular}{|c|c|c|c|c|}
\hline \multicolumn{2}{|r|}{ ACTION } & Ethical & Unethical & I don't know \\
\hline A & Selecting a contractor based on lowest bid price & $70.1 \%$ & $20.3 \%$ & $9.6 \%$ \\
\hline B & $\begin{array}{l}\text { Unbalancing a bid in an attempt to get money early to } \\
\text { finance later parts of the job }\end{array}$ & $20.2 \%$ & $61.2 \%$ & $18.5 \%$ \\
\hline $\mathrm{C}$ & $\begin{array}{l}\text { Taking a subcontractors bid and showing it to another } \\
\text { subcontractor with the aim of getting a lower bid price } \\
\text { - i.e. bid shopping }\end{array}$ & $24.7 \%$ & $65.7 \%$ & $9.6 \%$ \\
\hline $\mathrm{D}$ & $\begin{array}{l}\text { Two or more contractors agreeing before the bid to } \\
\text { increase their bid prices }\end{array}$ & $20.3 \%$ & $68.9 \%$ & $10.7 \%$ \\
\hline $\mathrm{E}$ & $\begin{array}{l}\text { A contractor providing an owner's representative with } \\
\text { a gift in order to get preferential treatment }\end{array}$ & $21.9 \%$ & $\mathbf{7 3 . 0 \%}$ & $5.1 \%$ \\
\hline $\mathrm{F}$ & $\begin{array}{l}\text { A contractor is using materials for construction that do } \\
\text { not meet required specifications }\end{array}$ & $0.0 \%$ & $98.3 \%$ & $1.7 \%$ \\
\hline G & Contractor performing work in an unsafe manner & $1.1 \%$ & $91.0 \%$ & $7.9 \%$ \\
\hline $\mathrm{H}$ & Overstating previous work experience & $12.9 \%$ & $76.4 \%$ & $10.7 \%$ \\
\hline I & $\begin{array}{l}\text { Claiming to have submitted required documents when } \\
\text { you have not }\end{array}$ & $0.0 \%$ & $97.2 \%$ & $2.8 \%$ \\
\hline $\mathrm{J}$ & Not reporting a co-worker stealing tools & $1.1 \%$ & $94.4 \%$ & $4.5 \%$ \\
\hline $\mathrm{K}$ & Contractor billing an owner for work not completed & $6.8 \%$ & $89.3 \%$ & $4.0 \%$ \\
\hline $\mathrm{L}$ & $\begin{array}{l}\text { Contractor delaying payment to a subcontractor until } \\
\text { receiving payment from owner }\end{array}$ & $47.2 \%$ & $31.5 \%$ & $21.3 \%$ \\
\hline M & $\begin{array}{l}\text { Installing approved but not preferred equipment on a } \\
\text { project }\end{array}$ & $63.5 \%$ & $20.8 \%$ & $15.7 \%$ \\
\hline
\end{tabular}

The academic integrity action "Working in groups on take-home exams" was matched by the students with $61.0 \%$ with the professional integrity action "Two or more contractors agreeing before the bid to increase their bid prices". Here the authors expected to see the students identifying working in groups for an exam as collusion in a professional setting, and with $61 \%$ of the students making this responding as such it is clear that students are making that connection. 
The academic integrity action "Submitting or copying homework assignments from previous terms", was matched the highest by the students with $32.5 \%$ with the professional integrity action "Sharing a subcontractor's quote with another subcontractor to get a lower price". Even though that was the connection expected by the authors, the low percentage suggests that not all of the students clearly identify that these actions are analogous.

Similarly with the final academic integrity action "Copying from an unapproved reference sheet during a closed book test or quiz", was matched the highest with "A contractor using materials for construction that do not meet required specifications" with a percentage of $46.1 \%$. The connection was again the expected one, but once again the low percentage suggests that the analogy is not completely grasped by the students.

Table 3: Third survey questions and results

\begin{tabular}{|c|c|c|c|c|c|c|}
\hline & $\underline{\text { ACTION }}$ & $\begin{array}{l}\text { Witnessing } \\
\text { a case of } \\
\text { cheating in } \\
\text { class and } \\
\text { not } \\
\text { reporting it } \\
\text { to the } \\
\text { instructor }\end{array}$ & $\begin{array}{l}\text { Claiming to } \\
\text { have } \\
\text { handed in } \\
\text { an } \\
\text { assignment } \\
\text { or an exam } \\
\text { when you } \\
\text { did not } \\
\end{array}$ & $\begin{array}{l}\text { Working in } \\
\text { groups on } \\
\text { take-home } \\
\text { exams }\end{array}$ & $\begin{array}{l}\text { Submitting } \\
\text { or copying } \\
\text { homework } \\
\text { assignments } \\
\text { from } \\
\text { previous } \\
\text { terms }\end{array}$ & $\begin{array}{c}\text { Copying } \\
\text { from an } \\
\text { unapproved } \\
\text { reference } \\
\text { sheet during } \\
\text { a closed } \\
\text { book test or } \\
\text { quiz }\end{array}$ \\
\hline 1 & $\begin{array}{l}\text { A contractor providing an owner's } \\
\text { representative with a gift in order to } \\
\text { get preferential treatment }\end{array}$ & $2.0 \%$ & $0.0 \%$ & $2.1 \%$ & $3.2 \%$ & $11.7 \%$ \\
\hline 2 & $\begin{array}{l}\text { Claiming to have submitted required } \\
\text { documents when you have not }\end{array}$ & $0.0 \%$ & $90.0 \%$ & $0.7 \%$ & $3.9 \%$ & $1.3 \%$ \\
\hline 3 & $\begin{array}{l}\text { Unbalancing a bid in an attempt to } \\
\text { get money early to finance later parts } \\
\text { of the job }\end{array}$ & $3.3 \%$ & $0.0 \%$ & $2.1 \%$ & $13.0 \%$ & $9.7 \%$ \\
\hline 4 & $\begin{array}{l}\text { A contractor using materials for } \\
\text { construction that do not meet } \\
\text { required specifications }\end{array}$ & $2.0 \%$ & $0.7 \%$ & $2.7 \%$ & $20.1 \%$ & $46.1 \%$ \\
\hline 5 & $\begin{array}{l}\text { Contractor billing an owner for work } \\
\text { not completed }\end{array}$ & $0.0 \%$ & $8.7 \%$ & $1.4 \%$ & $16.9 \%$ & $2.6 \%$ \\
\hline 6 & $\begin{array}{l}\text { Two or more contractors agreeing } \\
\text { before the bid to increase their bid } \\
\text { prices }\end{array}$ & $0.7 \%$ & $0.7 \%$ & $61.0 \%$ & $9.7 \%$ & $4.5 \%$ \\
\hline 7 & $\begin{array}{l}\text { Not reporting a co-worker stealing } \\
\text { tools }\end{array}$ & $89.5 \%$ & $0.0 \%$ & $0.0 \%$ & $0.6 \%$ & $1.3 \%$ \\
\hline 8 & $\begin{array}{l}\text { Sharing a subcontractor's quote with } \\
\text { another subcontractor to get a lower } \\
\text { price }\end{array}$ & $2.6 \%$ & $0.0 \%$ & $30.1 \%$ & $32.5 \%$ & $22.7 \%$ \\
\hline
\end{tabular}

\section{Observations and Conclusions}

At the end of the series of surveys, it was observed that the majority of the students recognize almost all potential violations of academic integrity. As seen in Table 1, and as concluded by 
Carpenter et al. ${ }^{4}$, students seem to distinguish between violations that they consider cheating and violations that they consider unethical. The majority of the actions that they consider unethical normally take place outside the classroom examples of which are "Asking another student about questions on an exam you have not yet taken" and "Working in groups on web-based quizzes". What also seemed surprising to the authors was that more than a third of the students (36.6\%) did not consider "Working in groups on take-home exams" to be cheating.

Regarding the frequency of cheating (survey 1), it was observed that students self admittedly violate academic integrity on a regular basis, with the highest violations being "Asking another student about questions on an exam you have not yet taken" with $59.5 \%$ of students performing that action at least once or more in the past year, and with 51.3\% "Working in groups on webbased quizzes". The authors believe that the percentage of the violations is higher than the one self-reported in the survey by the students, the extent of which might be very difficult to estimate.

Regarding professional integrity (survey 2), the majority of the students recognized the actions that can be considered unethical suggesting that they are beginning to have an understanding for the industry and the ethical norms for professional ethical behavior within it. The understanding though is not an indication of actually performing within these expected norms of behavior. As observed in Table 1 (academic integrity) the understanding of the violation, does not prevent unethical behavior, or in the case of academic integrity, cheating.

The link between academic and professional integrity is not always evident to students, as seen is Table 3. For two of the academic integrity violations, students were able to recognize the equivalent professional integrity violation at a high percentage (90.0\% and $89.9 \%$ ), while for the other three the percentages were lower $(61.0 \%, 32.5 \%$ and $46.1 \%)$. These results suggest that it is important for students to recognize the link between academic and professional integrity, and that can be achieved through the reinforcement of this link in the class room.

\section{Recommendations}

The results shown in this study are merely the product of a preliminary investigation of the views and perceptions of civil engineering technology and construction management students in one university, on the topic of academic and professional integrity. In order to generalize the results to the rest of the country it is important to repeat a similar investigation at other equivalent departments in other universities.

As observed, students do recognize violations of academic and professional integrity, but the link between these types of violations might not always be apparent to them. It is extremely important for educators to reinforce the connection and stress the significance of professional integrity in the classroom and plant the seed of ethical professional behavior early on. 


\section{References}

1.Jimenez, L.O., E. O'Neill-Carrillo, and M. Rodriguez. An introductory learning module on ethics and academic integrity for freshman engineering students. in 2009 39th IEEE Frontiers in Education Conference. Imagining and Engineering Future CSET Education (FIE 2009), 18-21 Oct. 2009. 2009. Piscataway, NJ, USA: IEEE.

2.Carpenter, D.D., et al., Engineering students' perceptions of and attitudes towards cheating. Journal of Engineering Education, 2006. 95(3): p. 181-194.

3.McCabe, D., Classroom cheating among natural science and engineering majors. Science and Engineering Ethics, 1997. 3(4): p. 433-445.

4.Carpenter, D.D., T.S. Harding, and C.J. Finelli, The Implications of Academic Dishonesty in Undergraduate Engineering on Professional Ethical Behavior, in World Environmental and Water Resource Congress 2006. 2006. p. 1-12.

5.NSPE. NSPE Code of Ethics. 2014 [cited 2014 January, 4]; Available from: http://www.nspe.org/Ethics/CodeofEthics/index.html.

6.AIA. 2012 Code of Ethics \& Professional Conduct. 2014 [cited 2014 January, 4]; Available from: http://www.aia.org/aiaucmp/groups/aia/documents/pdf/aiap074122.pdf.

7.ASCE. The ASCE Code of Ethics. 2012 [cited 2013 May 2]; Available from: http://www.asce.org/Leadershipand-Management/Ethics/Code-of-Ethics/.

8.CMAA. Code of Ethics. 2013 [cited 2014 January 4]; Available from: http://cmaanet.org/code-of-ethics.

9.Carpenter, D.D., et al. P.A.C.E.S. - A study on academic integrity among engineering undergraduates (preliminary conclusions) in 2002 ASEE Annual Conference \& Exposition. 2002. Montreal, Quèbec, Canada.

10.Carpenter, D.D., et al. Student Perceptions of Institutional and Instructor Based Techniques for dealing with Academic Dishonesty. in 32nd Frontiers in Educaion Conference. 2002. Boston, MA.

11.Bowen, P., P. Edwards, and K. Cattell. Corruption in the South African construction industry: A mixed methods study. in 28th Annual ARCOM Conference. 2012. Edinburgh, UK.

12.Parson, E., The construction industry's ethical dilemma. Electrical Construction and Maintenance, 2005. 104(8): p. 50-6. 